\title{
Boiling Water at Hot Creek-The Dangerous and Dynamic Thermal Springs in California's Long Valley Caldera
}

he beautiful blue pools and
impressive boiling fountains
along Hot Creek in east-central
California have provided
enjoyment to generations of
visitors, but they have also been
the cause of injury or death to
some who disregarded warnings
and fences. The springs and
geysers in the stream bed and
along its banks change location,
temperature, and flow rates
frequently and unpredictably.
The hot springs and geysers of
Hot Creek are visible signs of
dynamic geologic processes
in this volcanic region, where
underground heat drives thermal
spring activity.

In the Hot Creek Geologic Site, located in a narrow gorge 8 miles $(12 \mathrm{~km})$ east of the town of Mammoth Lakes, numerous hot springs flow into a snowmelt-fed stream. The area is managed by the U.S. Forest Service as a geologic interpretive site and has been a popular recreational area for fishing, swimming, hiking, bird watching, and photography. The U.S. Geological Survey (USGS)

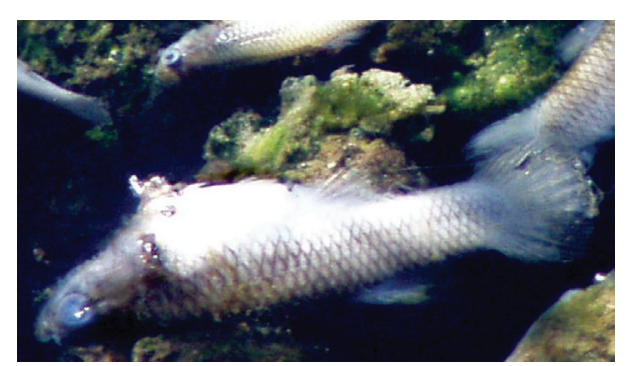

Conditions in Hot Creek can change very quickly. These fish - caught in a burst of high-temperature water-were cooked instantly. (USGS photo by Chris Farrar.)

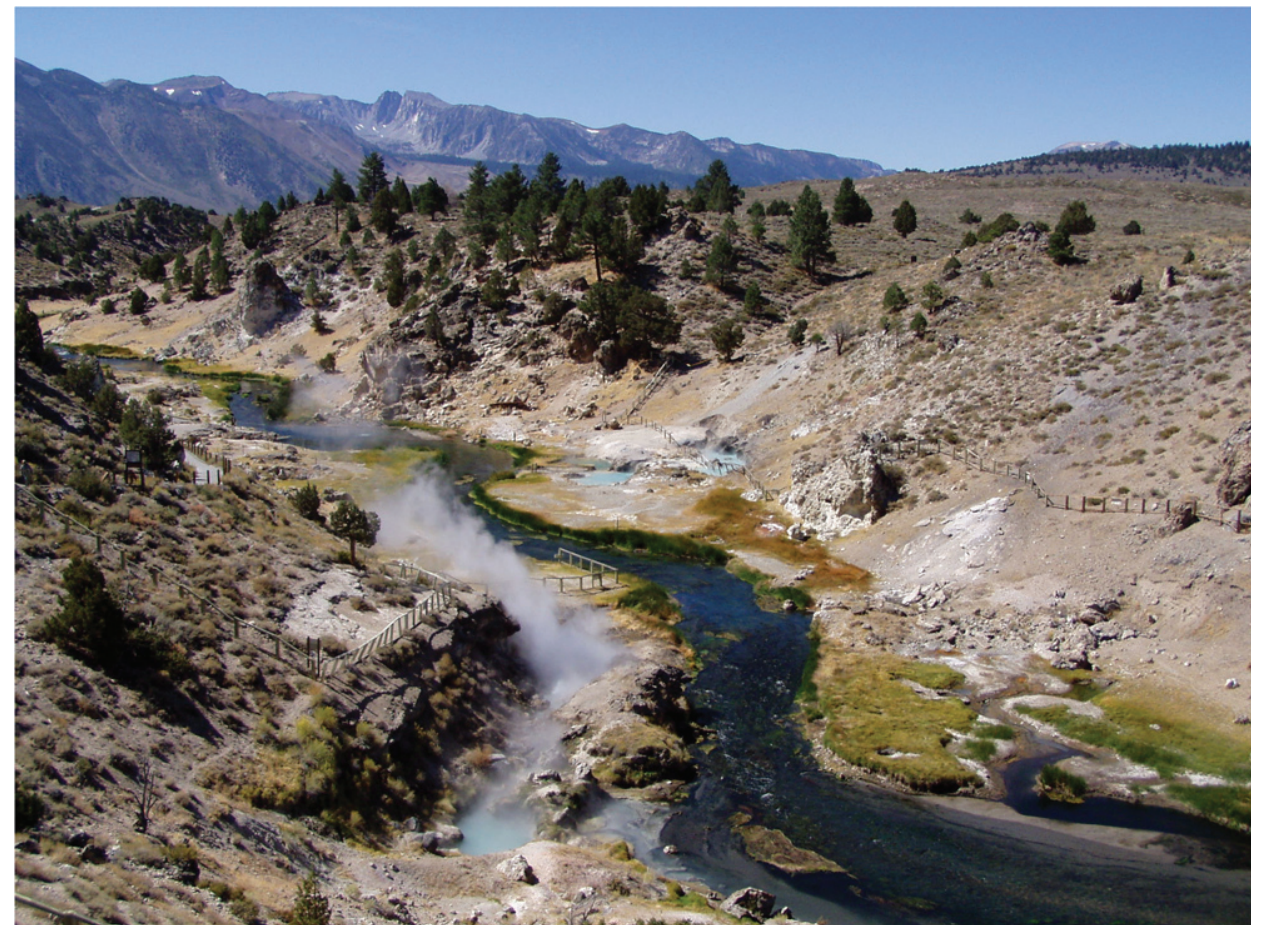

Hot Creek flows through the Long Valley Caldera in a volcanically active region of east-central California. This stretch of the creek, looking upstream to the southwest, has long been a popular recreation area because of the warm waters from its thermal springs. These springs, however, are unpredictable and can suddenly erupt with violence and at boiling temperature. Because of this danger, the U.S. Forest Service has had to close parts of the Hot Creek Geologic Site to visitors. (USGS photo by Chris Farrar.)

has long monitored spring activity, water temperatures and chemistry, and stream flow as part of a program that seeks to better understand volcanic unrest and possible geologic hazards throughout the region.

The attractions of Hot Creek, however, also harbor danger. The locations, discharge rates, and temperatures of springs often change. The larger and more vigorous springs flow from fractures in the volcanic rock (altered rhyolite) in Hot Creek gorge. When fractures become sealed by mineral deposition, spring discharge and temperature decline. When new fractures develop or sealed fractures reopen, spring discharge and temperatures can increase suddenly. Rock fracturing happens because the thermal area lies within a region of frequent earthquakes and active ground uplift (deformation). The changes in the locations and vigor of springs can be sudden and dangerous to unprepared visitors, especially if they stray beyond walkways and fences.

Since May 2006, springs in and near the most popular swimming areas have been "geysering" or intermittently spurting very hot, sediment-laden water as high as 6 feet ( $2 \mathrm{~m}$ ) above the stream surface. At times this geysering activity is vigorous enough to produce "popping" sounds audible from hundreds of feet away. The geysering usually lasts a few seconds and occurs at irregular intervals, with several minutes between eruptions. The unpredictability of this hazardous spring activity led the U.S. Forest Service to close parts of the Hot Creek Geologic Site in June 2006, and the closure has remained in effect to date (June 2007). 
The thermal springs in Long Valley Caldera have long been known to Native Americans. Many of the hot springs have special status with Native American tribes and have been used for spiritual and medicinal purposes. Early written records of the springs came from visits by pioneers and scientists- USGS scientist G.A. Waring visited thermal springs in Long Valley in 1908 and later wrote a paper describing hundreds of springs throughout California.

\section{Volcanic History of the Hot Creek Area}

The Hot Creek Geologic Site lies within the Long Valley Caldera, a large topographic depression formed 760,000 years ago during a massive volcanic eruption that produced extensive and thick deposits of ash
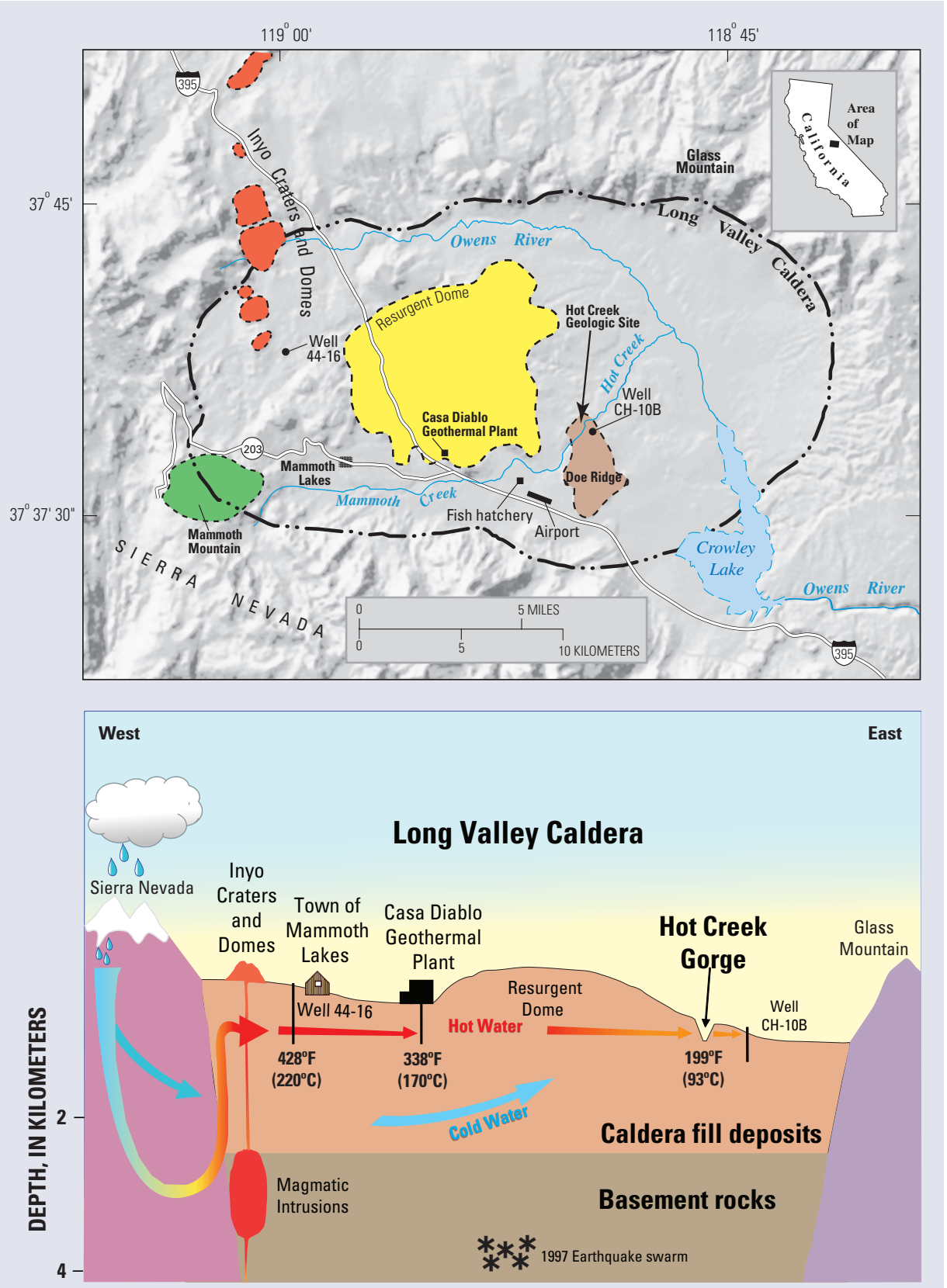

Simplified geologic map (top) and diagrammatic cross section (bottom) of Long Valley Caldera. The resurgent dome, Doe Ridge, Mammoth Mountain, and the Inyo Craters and Domes all reflect volcanic activity since 760,000 years ago, when a giant eruption formed the caldera. The thermal springs in Hot Creek are fed by Sierra Nevada snowmelt that seeps underground and migrates eastward, becoming heated to temperatures as high as $428^{\circ} \mathrm{F}\left(220^{\circ} \mathrm{C}\right)$ in the vicinity of partially molten rock (magma) beneath the western part of the caldera. The water cools as it migrates eastward beneath the ground (red arrows). The temperature at which water emerges in the springs at Hot Creek could be affected by changes in seismic activity, heat extraction, mixing with cooler water, and other factors. and pumice. A reservoir of partially molten rock (magma) beneath the caldera has produced subsequent volcanic eruptions. This activity formed many hills within the caldera, such as the 300,000 year-old Hot Creek rhyolite flow, known locally as Doe Ridge. The toe of that slow-moving lava entered a lake, where interaction with water altered the rhyolite and formed clay and perlite, a gray to black, glassy material with a pearly luster now exposed along the path from the parking area down into the gorge. After the lake receded, a stream cut the steep-sided gorge through the toe of the solidified lava.

This stream, known here as Hot Creek, begins its winding course some 11 miles $(17 \mathrm{~km})$ to the west as Mammoth Creek, flowing through a series of small lakes west of the town of Mammoth Lakes. The stream water is derived primarily from melting snow as it leaves Twin Lakes, 8,500 feet $(2,600 \mathrm{~m})$ above sea level. It is quite cold, rarely above $50^{\circ} \mathrm{F}\left(10^{\circ} \mathrm{C}\right)$. About 1.5 miles $(2.5 \mathrm{~km})$ upstream from the thermal area, Mammoth Creek is joined by warmer water from thermal springs in the Hot Creek State Fish Hatchery. From this point on, the stream is named Hot Creek even though water temperature seldom exceeds $68^{\circ} \mathrm{F}$ $\left(20^{\circ} \mathrm{C}\right)$ until it reaches the main thermal springs in the gorge.

\section{Why is Hot Creek Hot?}

In hydrothermal ("hot water") systems the circulation of ground water is driven by a combination of topography and heat sources. The system in Long Valley Caldera is recharged primarily from snowmelt in the highlands around the western and southern rims of the caldera. The meltwater infiltrates to considerable depths, where some is heated to at least $430^{\circ} \mathrm{F}\left(220^{\circ} \mathrm{C}\right)$ by hot rock near cooling magma beneath the Inyo Craters and Domes, 10 miles (16 km) west of Hot Creek. This volcanic chain extends from the western part of Long Valley Caldera northward to Mono Lake and has produced numerous eruptions over the past 40,000 years, the latest only a few hundred years ago. The heated water, kept from boiling by high pressure, still has lower density than cold water, and it rises along steeply inclined fractures to depths of 0.31.25 miles $(0.5-2 \mathrm{~km})$. It then flows eastward through rock layers to discharge points at the surface along Hot Creek and around Crowley Lake. The water temperature de- 


\section{THERMAL WATER INPUT TO HOT CREEK}

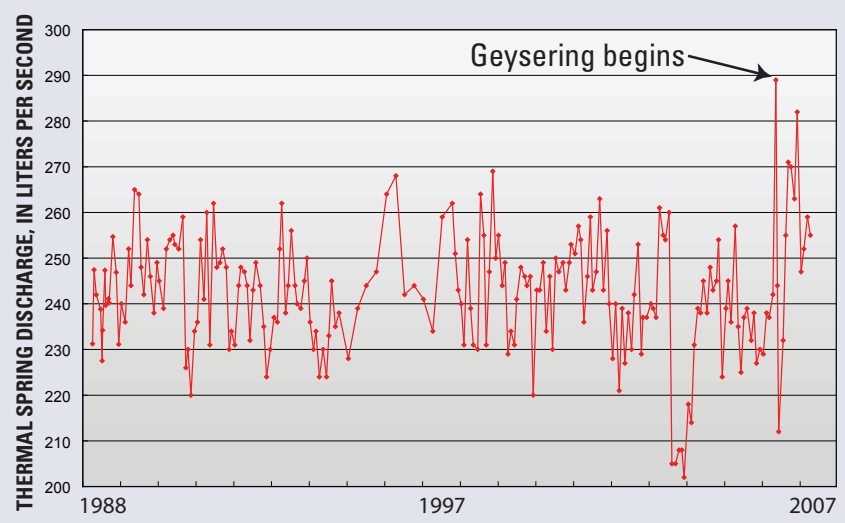

The U.S. Geological Survey monitors the thermal water discharge in Hot Creek gorge by measuring chloride concentration in the stream above and below the hot springs. The onset of geysering in 2006 was accompanied by a small spike in discharge. (1 liter $=0.264$ gallon.)

\section{DANGER COMES OUICKLY}
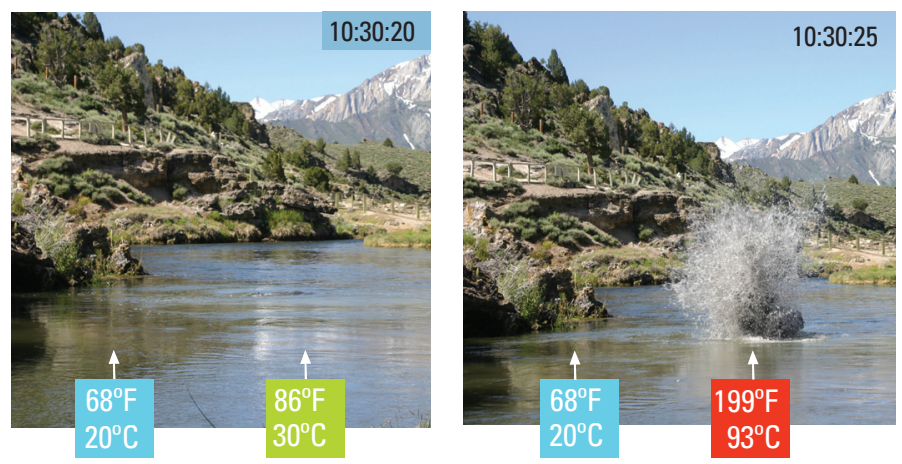

The temperature in Hot Creek can change in seconds. These photos were taken 5 seconds before and then during a violent geysering event, in which boiling water (at $199^{\circ} \mathrm{F}$ or $93^{\circ} \mathrm{C}$, the boiling point at this elevation) erupted above the surface. Any swimmer caught in this part of the creek would have been severely scalded. (Photos courtesy of Alix Ginter.) creases eastward because of heat loss and mixing with cold water, and in the springs near Crowley Lake temperatures are at only about $125^{\circ} \mathrm{F}\left(50^{\circ} \mathrm{C}\right)$.

The springs in Hot Creek all emerge along a stream section between two faults and discharge a total of about 8.5 cubic feet per second (about 240 liters per second) of hot water. This water flow represents nearly 70 percent of the total heat discharged by all thermal springs in Long Valley Caldera. The thermal springs farther east all discharge less water and at lower temperatures.

\section{Possible Causes of the Recent Changes}

Geysering activity similar to that which started in May 2006 also occurred along Hot Creek in 1980. That activity was during a period of greatly increased seismic (earthquake) activity and ground deformation. In 2006, however, local seismic activity and ground deformation were at the lowest levels in years, and the reason for this recent geysering is unclear. The change seems to be related to increased temperature in the shallow thermal ground water that supplies the springs. This increase was measured in the USGS monitoring well $\mathrm{CH}-10 \mathrm{~B}$,
330 feet $(100 \mathrm{~m})$ deep and located 0.6 mile (1 $\mathrm{km}$ ) south of the gorge. Water level in this well is at the same altitude as the Hot Creek springs, and the temperature at that level reached the boiling point at about the time when geysering began in Hot Creek. What caused the temperature increase in the aquifer is not known, but it may be a delayed response to an earthquake swarm in 1997 that could have opened new flow pathways for hot water.

An alternative explanation for the onset of geysering is increased pressure in the aquifer leading to increased flow rate at

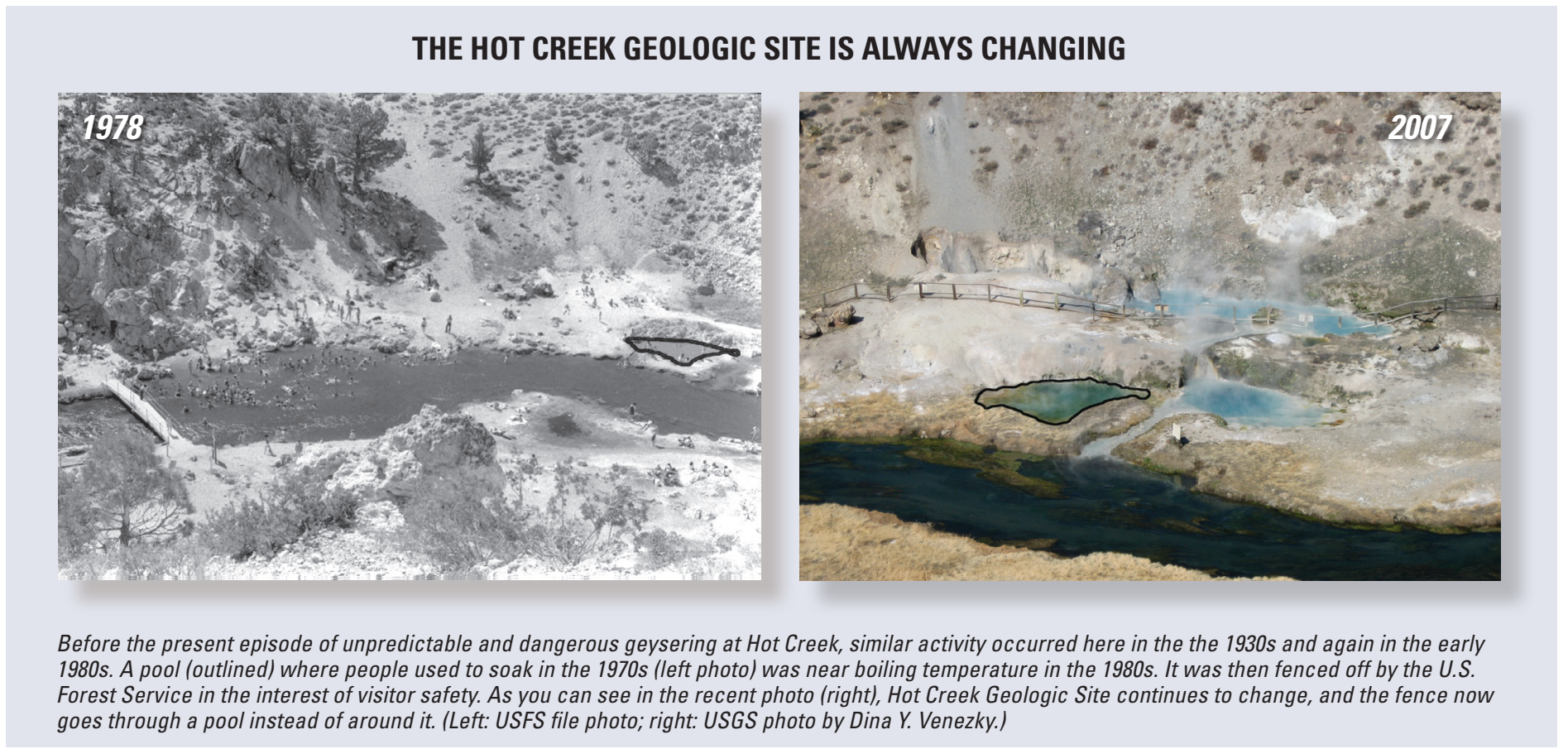


the springs. In 2006, following a winter of heavy snow, there was abundant snowmelt that would have increased pressure in the aquifer. USGS measurements show that the total hot-spring discharge fluctuated strongly in June 2006, but it later returned to values near the long-term average.

\section{What's in the Water?}

For several decades, the USGS has collected and analyzed water and gas samples from most of the streams, springs, and fumaroles (steam vents) in Long Valley Caldera, including those in the Hot Creek Geologic Site. The hot-spring water is naturally enriched in dissolved minerals. It is rich in sodium bicarbonate and contains high concentrations of arsenic, boron, and fluoride, all in excess of safe drinking-water standards. Stream water entering the thermal area is still relatively pure, but it leaves the area higher in dissolved substances because the mineralized hot-spring water mixes into the stream.

The springs and some areas of soil on the banks also discharge steam and other gases. Apart from steam, most of the gas is carbon dioxide, with minor amounts of hydrogen

\section{WHY ARE THE HOTTEST POOLS BLUE?}

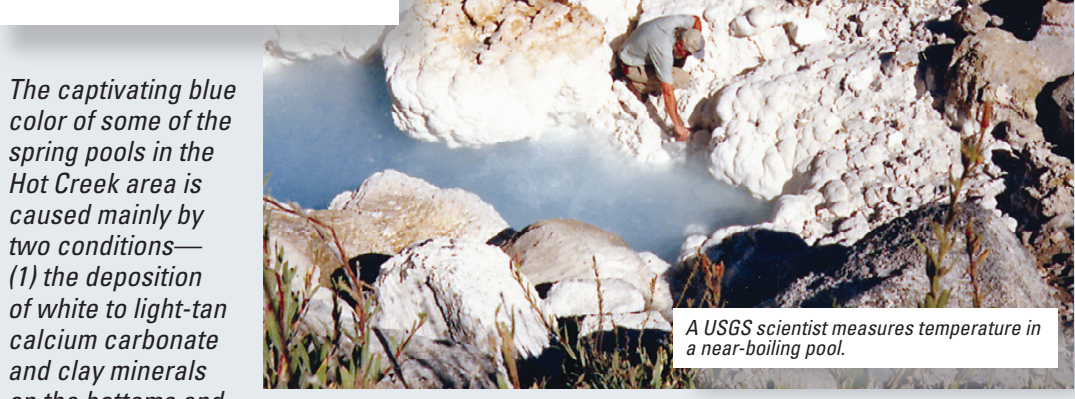

on the bottoms and sides of the pools provides a bright background to reflect light, and (2) the properties of water that absorb red wavelengths of light but reflect blue wavelengths give the reflected light a blue tinge. This is the same effect seen in plaster-lined swimming pools. The bluest pools at Hot Creek gorge also have fine particles of calcium carbonate or clay kept in suspension by the boiling action. In general, the blue pools are the hottest because in water cooler than about $160^{\circ} \mathrm{F}\left(70^{\circ} \mathrm{C}\right)$ bacterial and algal masses give a greenish or brownish cast to the water. (USGS photo by Rick Iwatsubo.)

sulfide (which smells like rotten eggs) and other gases. Gas bubbles can be seen rapidly rising through the water in places along the edge of the stream. Areas of steam venting are always present at Hot Creek, but their visibility increases as the air temperature drops or the humidity rises. The seasonal variations in air

\section{VISITING HOT CREEK SAFELY}

Visiting Hot Creek can be an enjoyable and rewarding experience, but you should be aware of the dangers and take them seriously. Know the hazards—boiling or scalding water, steam vents, unstable ground and boulders, hot ground or mud, swiftly flowing water, a stream with unpredictable currents, and water unfit for human consumption.

Follow these tips for your safety:

\section{- Keep a clear head and be observant-conditions can change quickly.}

\section{- Keep careful watch on children and pets (always keep pets on a leash).}

\section{- Follow directions and warnings on signs.}

\section{- Don't cross over fences or barriers, and stay on walkways.}

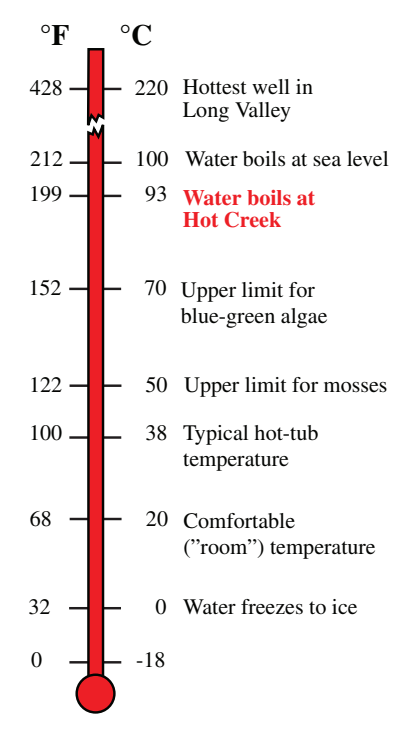

How to get there:

The Hot Creek Geologic Site is located northeast of the Mammoth-Yosemite Airport and is accessed from U.S. Highway 395 by the Hot Creek Hatchery Road. temperature and humidity can lead to a false appearance of big changes in steam discharge.

The quality and temperature of the stream water in Hot Creek is generally acceptable for sustaining aquatic organisms, including a robust population of wild trout. However, very rapid changes in thermal spring discharge can sometimes raise water temperatures high enough to kill unlucky fish and other organisms. Be careful that you do not fall victim to such a fate!

The work of USGS scientists, in cooperation with the U.S. Forest Service, investigating the hydrothermal features of Hot Creek and the geology of Long Valley Caldera is shedding new light on this fascinating area and its geologic hazards. This work is only part of the efforts of the USGS to study and monitor the Nation's volcanic regions and water resources.

Christopher D. Farrar, William C. Evans, Dina Y. Venezky, Shaul Hurwitz, and Lynn K.Oliver

Edited by Peter H. Stauffer Graphic design by Judy Weathers Banner design by Bobbie Myers COOPERATING ORGANIZATIONS U.S. Depatement of Agriculture, Forest Service

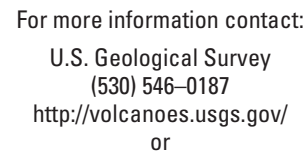

See also: Living with a restless caldera-

Long Valley, California (USGS Fact Sheet 108-96); Invisible $\mathrm{CO}_{2}$ gas killing trees at Mammoth Mountain, California (USGS Fact Sheet 172-96);

and Future eruptions in California's Long Valley areawhat's likely? (USGS Fact Sheet 073-97)

This Fact Sheet and any updates to it are available online at http://pubs.usgs.gov/fs/2007/3045 